\title{
Amerika Birleşik Devletleri ve Avrupa'da ortopedi asistan eğitimi: İnternet üzerinden eğitimin rolü var mı?
}

\section{Orthopaedics residents' education in the United States and in Europe: Does internet-based learning have a role?}

\author{
Filippo Familiari, Alan Gonzalez-Zapata \\ Division of Shoulder Surgery, Department of Orthopaedic Surgery, The Johns Hopkins University, Baltimore, Maryland, US
}

\begin{abstract}
Ortopedi asistan eğitimi gelişen ve sürekli değişen bir paradigmadır. Son zamanlarda, ortopedi eğitiminde asistan çalışma saatlerine, özellikle çalışma saatindeki kısıtlamalar konusuna duyulan ilgi artmıştır. Avrupa ve ABD'deki ortopedi asistan eğitim programlarında, çalışma saati kısıtlamaları bakımından farklılıklar vardır. Bu nedenle, internete dayalı eğitim ortopedi asistanının bilgi donanımı açısından büyük önem kazanmıştır. Ortopedi asistanını eğitmenin alternatif yöntemleri; sentetik veya kadavra kemikleri kullanan cerrahi beceri laboratuvarları, bilgisayar yazılımları üzerinden eğitim ve bilgisayar destekli simülatörlerdir. Bu derlemede amacımız, ABD ve Avrupa Birliği arasındaki farklılıklar üzerinde durmak ve ortopedi asistanının, özellikle board sınavlarına çalışırken kullanabileceği internete dayalı kaynakları incelemektir.
\end{abstract}

Anahtar sözcülkler: internet üzerinden eğitim; ortopedi asistanı; çalışma saati sınırları; board sınavları; ortopedi asistan birlikleri
Orthopaedic resident education is an evolving and continuously changing paradigm. Recently, the issue of resident work hours and, more specifically, work hour limits has received increased attention in orthopaedic residents education. Differences exist in work hour limits between orthopaedic residency programs in Europe and in the United States of America. Consequently, internet-based learning has gained a valued place in the knowledge armamentarium of the orthopaedic resident. Alternative methods to train orthopaedic residents are: surgical skills laboratories using synthetic or cadaver bones, PC-based training using software, and computerized simulators. Our purpose was to review existing differences in orthopaedic residency programs between the United States and the European Union, and to look at the available resources for education of orthopaedic residents on the internet with a special focus on orthopaedic resident preparation for board exams.

Key words: internet-based learning; orthopaedic resident; work hour limit; board exams; orthopaedic residents associations

\section{GiRiş}

Ortopedi asistan eğitimi sürekli gelişen ve değişen bir paradigmadır. Son zamanlarda, asistan çalışma saatleri, özellikle çalışma saatindeki kısıtlamalar tıp eğitimine olan dikkati arttırmıştır. ABD'deki Accreditation Committee for Graduate Medical Education (ACGME) çalışma saatlerini 80 saat ile sınırlamıştır. ${ }^{[1]} \mathrm{Bu}$ arada Avrupa Birliği, Avrupa Çalışma Süreleri Yönetmeliği (European Working Time Directive)'ne göre çalışma saatlerini 48 saat ile sınırlamıştır. ${ }^{[1]}$ Çalışma saati düzenlemelerine farklı tepkiler olmuştur; bazıları, azalan çalışma saatlerinin asistan eğitimini kötü yönde etkileyeceği görüşündedir. ${ }^{[2-5]}$

Yakın zamanda Wolf and Britton, ortopedi eğitiminde üç ana hedef olduğunu belirtmiş ve bunları şu

\section{INTRODUCTION}

Orthopaedic resident education is an evolving and continuously changing paradigm. Recently, the issue of resident work hours and, more specifically, work hour limits has received increased attention in medical education. The Accreditation Committee for Graduate Medical Education (ACGME) in the United States specifically limits the work week to 80 hours. ${ }^{[1]}$ Meanwhile, in the European Union, the European Working Time Directive, limits the work week to 48 hours. ${ }^{[1]}$ Reaction to work-hour regulations has been mixed with some of them underlying that reducing resident work-hours would compromise residents training. ${ }^{[2-5]}$

Recently, Wolf and Britton stated that "there are three main goals of orthopaedic training: 1 ) education

- Illetişim adresi: Filippo Familiari, MD, Division of Shoulder Surgery, Department of Orthopaedic Surgery, The Johns Hopkins University, Baltimore, Maryland, United States Tel: +39328-9182295 e-posta: filippofamiliari@gmail.com

- Geliș tarihi: 24 Ekim 2014 Kabul tarihi: 24 Ekim 2014 
şekilde sıralamıştır: 1) ortopedi alanındaki sık görülen hastalık ve durumların eğitimi, 2) ilgili temel ve klinik bilimlerin öğretilmesi ve 3 ) ortopedideki cerrahi işlemlerin ve tekniklerin öğretilmesi. ${ }^{[6]}$ Ortopedideki eğitim kaynakları: didaktik dersler; klinik alandaki tecrübe; ameliyathanedeki tecrübe; kadavra ve sentetik kemikler üzerinde, bilgisayar yazılımları ve bilgisayarlı simülatörler yardımı ile cerrahi beceri laboratuvarlarıdır. Ek olarak, asistanlar ortopedi kaynaklarından, dergilerinden ve internetteki kaynaklardan (örneğin; internet üzerinden eğitim) daha fazla bilgi edinebilirler. ${ }^{[6,7]}$

İnternet, otropedi cerrahının bilgi kaynağı olarak çok büyük bir yer edinmiştir. Ortopedistler için daha fazla kaynak ulaşılabilir oldukça ve mobil internet erişimi geliştikçe, eğitim için internette geçirilen zaman artmıştır. Ancak, var olan bilginin kalitesi tartışılabilir. ${ }^{[8-10]}$ Sinkov ve arkadaşları, 2004 yılında, üç tıp fakültesindeki asistanlar ve uzmanlar üzerinde; ayaktan hasta kliniklerinde, acil kliniklerde, ameliyat öncesi planlamada ve asistanlar için seviye tespit sınavına hazırlanmada internetin kaynak olarak kullanımı üzerine bir araştırma yaptılar. ${ }^{[11]}$ Yazarlar, asistanların \%100'ünün (35/35) internet kullandığını ve eğitim için internette harcanan zamanın haftalık ortalama 3,1 saat olduğunu tespit ettiler. (aralık: $1-8,5$ saat) Ayaktan vakalar, acil hastalar ve ameliyat öncesi planlama için en sık kullanılan internet kaynağının online textbook'lar, en sık kulllanılan üç sitenin ise Wheeless's Textbook of Orthopaedics, The American Academy of Orthopaedic Surgeons ve Orthopedics Hyperguide siteleri olduğu buldular. Uzmanların \%79'u (19/24) interneti öğrenmek için kullanmıştı. Ortalama haftada 1,4 saat (aralık: 0,25-3 saat) bu amaç için internet kullanılmıştı. Yazarlar, uzmanların interneti en çok ameliyat öncesi planlama için, en az da acil şartlarda kullandığını gösterdiler. Araştırmaya göre, en sık kullanılan çevirimiçi siteler: American Academy of Orthopaedic Surgeons, Wheeless's Textbook of Orthopaedics ve AO North America. ${ }^{[11]}$

Bu çalışmada amacımız, ABD ve Avrupa Birliği'ndeki asistan eğitim programları arasında var olan farklılıklar üzerinde kısaca durmak ve ortopedi asistanları için internet üzerindeki kaynakları incelemek olacaktır. Bunu yaparken ayrıca, ortopedi asistanlarının hazırlanması gereken board sınavları üzerinde özellikle durulacaktır.

\section{AMERIKA BIRLESSiK DEVLETLERI'NDE ORTOPEDI ASISTANLIĞI}

Birleşik devletlerdeki ortopedi asistanı programlarının çoğu beş yıllıktır; bazıları altı yıl veya üzerinde in the diseases and conditions that are common to the field of orthopaedic surgery, 2) education in the pertinent basic and clinical sciences, and 3 ) education in the procedural skills and operative techniques of orthopaedics". ${ }^{[6]}$ Educational resource in orthopaedics include didactic lectures, experience in the clinical setting, experience in the operating room, and surgical skills labs using cadaver models or synthetic bones, software tools, and computerized simulators. Additionally, residents can gain more knowledge from reading orthopaedic texts, orthopaedic journals, and from web-based resources (i.e. internet-based education) ${ }^{[6,7]}$

The internet has gained a valued place in the knowledge armamentarium of the orthopaedic surgeon. The amount of time spent learning on the internet has increased as more resources has become available and as the mobile internet access has improved. The quality of the information presented, however, remains questionable. ${ }^{[8-10]}$ In 2004, Sinkov et al. conducted a survey among the orthopaedic residents and attending physicians in three medical facilities to determine their use of internet resources in the outpatient clinic and emergency room settings, in preoperative planning, and, in the case of residents, in preparation for in-training board examinations. ${ }^{[11]}$ The authors found that $100 \%(35 / 35)$ of the residents used the internet for learning with time spent on internet learning averaged 3.1 hours (range, 1-8.5 hours) per week. Online textbooks were the most commonly used internet resource in the settings of outpatient clinic, emergency room, and preoperative planning, and the top three most commonly used online sites were Wheeless's Textbook of Orthopaedics, the American Academy of Orthopaedic Surgeons' website, and Orthopedics Hyperguide. Seventy-nine percent $(19 / 24)$ used the internet for learning. The average time spent on this activity was 1.4 hours (range, $0.25-3$ hours) per week. The authors showed that the attending physicians used the internet most often during preoperative planning and least often in the emergency room setting. The top three most commonly used online sites were the American Academy of Orthopaedic Surgeons' website, Wheeless's Textbook of Orthopaedics, and AO North America. ${ }^{[11]}$

Our purpose was to briefly review existing differences in orthopaedic residency programs between the United States and the European Union, and to look at the available resources for education of orthopaedic residents on the internet, with a special focus on orthopaedic resident preparation for board exams.

\section{ORTHOPAEDIC RESIDENCY IN THE UNITED STATES}

Most of the orthopaedic residency programs in the United States last 5 years although some may take 6 
sürebilir. Başlangıç yılı eğitimi (intern yılı) genel cerrahi, plastik cerrahi, acil servis yoğun bakım ve anestezi rotasyonlarından oluşur. Doktora sonrası (post graduate) ikinci yıl, yani PGY2'den sonra asistanlar, şef asistanın (PGY5) gözetiminde olurlar ki bu büyük oranda acil servis ve ameliyathanedeki pratikleri içerir. Asistanlar, başlangıçtan itibaren eğitim içi değerlendirmeye tabi tutulurlar (Orthopaedic In-Training Exam, OITE). Ortopedi tanı ve tedavileri, olgu temelli tartışmalar ile günlük olarak yapılır. Akredite bir asistanlık programını tamamladıktan sonra, adaylar akredite alt dal bir fellowship yapma şansına sahiptir. Bu, akademik kariyer yapmak, daha popüler olan veya daha ileri bir yan dalda özelleşmek için bir yoldur. ${ }^{[12]}$

Dahası, ortopedi asistanlık program sonrası board sertifikası almaya aday olunabilir. The American Board of Orthopedic Surgery (Amerikan Ortopedik Cerrahi Kurulu), board sertifikasyonunun yapıldığı sınavları yapmakla yükümlü ve eğitim standardizasyonundan sorumludur. Akredite bir asistan eğitim programını bitirdikten sonra, aday sadece yazılı olan birinci evre sınavı alabilir. Sınavın ikinci kısmını almak için 22 ay pratik yapması ve birinci kısmı tamamlamış olması gerekir. Sınavın ikinci kısmı sözlü şeklindedir ve aday belirlenmiş bir altı aylık süreçte gerçekleştirmiş olduğu ameliyatların bir listesini de sunmak zorundadır.

\section{Uzmanlık Eğitim Gelişim Sınavı (OITE)}

İnternetteki asistana yönelik sınırsız sayıda eğitim materyallerinin çoğu Türkiye'deki karşılığı Uzmanlık Eğitim Gelişim Sınavı olan Orthopaedic In-Training Exam (OITE) sınavına yöneliktir. ${ }^{[13]}$ Amerika'daki asistanların OITE sınavına yönelik kaynak materyal bulması en önemli konu gibidir. Bu bağlamda, Kruger ve arkadaşları tarafından yapılan bir araştırmada, ortopedide en yararlı ve en fazla kullanılan üç gözden geçirme kaynağı tespit edilmiştir: 1) Miller's Review of Orthopaedics, 5th edition, 2) American Academy of Orthopaedic Surgeons Comprehensive Orthopaedic Review ve 3) OrthoBullets, www.orthobullets.com. ${ }^{[14]}$ Yazarlar, Miller's Review of Orthopaedic (\%60) ve American Academy of Orthopaedic Surgeons Comprehensive Orthopaedic Review (\%62) kitaplarıla kıyaslandığında, OrthoBullets'ta $(\% 99,4)$, OITE sınavına yönelik çok daha fazla cevap olduğunu tespit etmişlerdir ( $p<0,0001)$. Dahası, OITE'ye çalışan ve OrthoBullets kullanan asistanların, Miller's Review of Orthopaedics veya American Academy of Orthopaedic Surgeons Comprehensive Orthopaedic Review kitabını kullananlardan çok daha fazla, eski sorulan soruları görebildiğini ortaya koymuşlardır $(p<0.0001) .{ }^{[14]}$ years or more. Initial training (the "internship") involves experience in general surgery as well as plastic surgery, emergency medicine, intensive therapy unit and anaesthesia. From post-graduate year 2 (PGY2) and above, trainees are supervised by the chief resident (PGY5); this largely involves practical experience in the emergency room and the operating theatre. Residents are subject to continuous in-training assessment as well as yearly examinations (Orthopaedic In-Training Exam, OITE). Orthopaedic diagnosis and treatment are taught through discussion of specific cases and this is done on a daily basis. On completion of the accredited residency, the candidate has the choice of attending an accredited sub-specialty fellowship. This may be a route to an academic career, which is a significantly popular choice, or a route to further subspecialisation. ${ }^{[12]}$

Furthermore, following completion of the orthopaedic residency programme, the candidate is eligible to acquire board certification. The American Board of Orthopedic Surgery is responsible for maintenance of educational standards and is involved with examinations to acquire board certification. Upon completion of an accredited residency, the candidate may sit the Part 1 examination which is purely written. In order to sit the Part 2 examination, they must have been practising for 22 months and have completed the Part 1. Part 2 consists of oral examinations, in addition to which candidates must submit a list of all their surgical procedures performed during a defined 6-month period.

\section{The Orthopaedic In-Training (OITE) Exam}

Considering the apparently endless quantity of educational material available online to residents today, ${ }^{[13]}$ it seems pivotal to find sources that provide residents in the United States with the most material that seems likely to be tested for the OITE Exam. In an effort to address this issue, Krueger et al. performed a study to determine which of the three widely used orthopedic review sources (Miller's Review of Orthopaedics, 5th edition; American Academy of Orthopaedic Surgeons Comprehensive Orthopaedic Review; and OrthoBullets, www.orthobullets.com) was the most valuable tool. ${ }^{[14]}$ The authors reported that significantly more answers for preparing the OITE Exam were found on OrthoBullets (99.4\%) compared with Miller's Review of Orthopaedics $(60 \%)$ and American Academy of Orthopaedic Surgeons Comprehensive Orthopaedic Review (62\%) $(p<0.0001)$. Furthermore, they found that residents using OrthoBullets to review for the OITE were exposed to significantly more answers of previously asked OITE questions than residents using Miller's 


\section{AVRUPA BIRLIĞiNDE ORTOPEDI ASISTANLIĞI}

\section{Birleşik Krallık}

Tıp fakültesi sonrası ilk iki yıllık eğitim, genel pratisyenlik dahil, çeşitli disiplinlerde her biri dört ay süren rotasyonlar şeklindedir ve bu ilk iki yıla Foundation Programme (FY1 ve FY2) yılları denir. Bu ilk iki yılın başarılı bir şekilde tamamlanmasının ardından, asistanların sekiz yıl süren Specialty Training (ST) (branşlaşma eğitimi) adı verilen bir eğitimi tamamlaması beklenir. ST yılları, şu anki uygulamada, üçe bölünmüştür. illk dönem (ST1 ve ST2) iki yıl sürer ve dört veya altı aylık cerrahi dal rotasyonlarından oluşur; burada amaç, bu süre dahilinde The Royal College of Surgeons sınavını vermektir. ${ }^{[12]}$

İkinci dönem (ST3-ST6) daha yüksek seviyede ortopedi uzmanı eğitimidir ve dördüncü yıldan sonra asistan, Intercollegiate Specialty Examination (FRCS[Orth]) denilen ve Amerikan board sınavına eşdeğer olan sınavı almaya hak kazanır. Üçüncü dönem (ST7 ve ST8 yılları) alt dal tecrübesini arttırmak için geçirilir. ST dönemindeki asistanların değerlendirilmesi 6-12 aylık süreler ile olur. ${ }^{[12]}$

\section{Almanya}

Almanya'da, asistanlar ortopedi ve travmatoloji uzmanı olmak için eğitimde en az altı yıl geçirirler. Ancak board'a girebilmek için adaylar German Medical Association (Deutsche Ärztekammer) tarafindan belirlendiği şekilde cerrahi olan ve cerrahi olmayan olgularını biriktirip sunmak zorundadırlar. ${ }^{[15]}$

En belirgin fark, ABD'deki ortopedi asistanların board'a girebilecek yeterlilikte olana kadar belli bir süre eğitim almak zorunda olmalarıdır. Çarpıcı olan; Amerika'daki asistanlar, eğitim sırasında Alman meslektaşlarına göre belirgin olarak yüksek sayıda cerrahi işlemi daha kısa bir sürede yapmaktadırlar. ${ }^{[15]}$

\section{Avrupa Ortopedi ve Travmatoloji Board (EBOT) sinavı}

ilk Avrupa Ortopedi ve Travmatoloji Board (EBOT) sınavı, 2000 yılında Yunanistanın Rodos adasında yapılmıştır. ${ }^{[16]}$ Sınavın formatı yıllar içinde daha kapsamlı olacak şekilde değişmiştir ve halihazırda katılımcı sayısı gittikçe artmaktadır. Sınav, 2011 yılından beri, elektif ortopedik konular, travma ve temel bilimlerin tüm müfredatını kapsayacak şekilde iki bölümden oluşur.

Bu her iki bölüm de yılda iki kez yapılmaktadır. Federation of Orthopaedic Trainees in Europe (FORTE) ortopedi asistan eğitiminde ana bir rol üstlenmektedir. FORTE, EBOT sınavına hazırlanmakta
Review of Orthopaedics or American Academy of Orthopaedic Surgeons Comprehensive Orthopaedic Review $(p<0.0001) \cdot{ }^{[14]}$

\section{ORTHOPAEDIC RESIDENCY IN THE EUROPEAN UNION}

\section{The United Kingdom}

Initial training includes a 2-year Foundation programme (FY1 and $F Y 2$ years) following qualification after medical school which consists of four months each in a broad range of disciplines to include medical specialties such as general practice. After successful completion of the FY1 and FY2 years, the trainee is required to compete for Specialty Training (ST) which is currently an eight-years duration programme. The ST years are currently divided into three phases. The first phase is of two years' duration (ST1 and ST2) and consists of four- or sixmonth rotations in surgical specialties, the expectation being that the membership of The Royal College of Surgeons' examinations be completed within this time-frame. ${ }^{[12]}$ The second phase (ST3 to ST6) is to be spent in higher specialist orthopaedic training and after the fourth year (ST6) of training, the trainee is eligible to sit the final intercollegiate specialty examination (FRCS[Orth]), which is comparable to the American board examination. The third phase (ST7 and ST8 years) is to be spent gaining subspecialty experience. Assessment of trainees in the ST is performed on a 6-12-monthly basis. ${ }^{[12]}$

\section{Germany}

In Germany, a resident in training to become an orthopedic surgeon must fulfill a minimum of six years of training. In order to become board eligible, however, each candidate must log a defined caseload of operative and nonoperative procedures, as defined by the German Medical Association (Deutsche Ärztekammer). ${ }^{[15]}$

In sharp contrast, orthopedic residents in the United States face a defined duration of training until they become board eligible. Strikingly, US residents perform a significantly higher number of surgical procedures during a shorter period of time, compared to their German colleagues in training. ${ }^{[15]}$

\section{The European Board of Orthopaedics and Traumatology (EBOT) Exam}

The first European Board of Orthopaedics and Traumatology (EBOT) Exam took place in Rhodes, Greece in 2000. ${ }^{[16]}$ The format of the examination has 
kullanılacak ve eğitimi tamamlayıcı bir materyal üzerinde çalışmaktadır.

Şu anda FORTE, ortopedi ve travmatolojinin tüm yönlerini kapsayan ve board sınavlarına çalışan asistan ve fellow'lara yönelik bir çalışma kitapları serisi (Study Guide Book Series) üzerinde çalışmaktadır. Dahası; FORTE, OrthoBullets (www.orthobullets.com) ile yakın işbirliği içinde ortopedi asistanlarına yönelik bir internet üzerinden eğitim sistemi üzerinde de çalışmaktadır.

\section{TARTIŞMA}

American Board of Orthopaedic Surgery (ABOS) ortopedi asistanı eğitiminde olması gereken asgari gereksinimleri şu şekilde belirlemiştir: 1) On iki ay, erişkin ortopedisi 2) On iki ay, kırık ve travma 3) Altı ay, çocuk ortopedisi ve 4) Altı ay, temel ve/veya klinik alt dallar. Bütün bunlara rağmen, geçtiğimiz on yılda Avrupa ve ABD'de uygulanmaya başlanan çalışma süresi kısıtlamaları, asistanların gerçek tecrübe alma sürelerini azaltmıştır. ${ }^{[17]}$ Pek çok kimse, bu azalan sürelerden dolayı asistanların gereken tecrübeyi biriktirmek için daha çok zamana ihtiyacının olduğunu, ayrıca mesleğin ince noktalarının öğrenecek yeterli zamanlarının kalmadığını belirtmiştir. Asistanlık eğitiminin amacı, becerikli ve tek başlarına genel bir ortopedistin yapabileceği ameliyatları yapabilecek uzmanlar yetiştirmek olmalıdır. ${ }^{[17]}$

Son zamanlarda ameliyathane dışında cerrahi becerileri arttırmak için alternatif yöntem arayışı vardır. ${ }^{[7]}$ Kadavra üzerinde eğitim, 16. yy'dan beri eğitimin bir parçasıdır ${ }^{[18]}$ ve doğrudan hastalar üzerinde cerrahi uygulama öncesi asistan eğitiminin temel taşlarından birisidir. ${ }^{[19]}$ Bu tarz eğitimin ana avantajı, eğitilenin gerçek anatomiyle yüzyüze kalmasıdır. 20 yy.'ın ikinci yarısında, kadarva kemiklerin yerini alacak sentetik veya plastik kemik modeller geliştirilmiş, temel ortopedik becerilerin öğrenilmesi için kullanılmış ve bunların ortopedi asistan eğitimindeki önemi anlaşılmıştır. Geçtiğimiz on yılda, pek çok ortopedi asistanlık programı kendi cerrahi beceri laboratuvarını kurmuştur; böylece, daha az riskli ve daha az gerilimli ortamlarda eğitim olanağı bulunmuştur. Bunlardan da öte, simülasyona dayalı eğitim yöntemleri arasında sentetik veya kadavra kemikler üzerinde cerrahi beceri laboratuvarında eğitim, bilgisayar destekli yazılımlar ile eğitim ve bilgisayarlı simülatörler sayılabilir. Simülatör ile artroskopi eğitimi, son zamanlarda artroskopik cerrahinin endikasyon aralığının hızla genişlemesiyle daha da önem kazanmıştır. ${ }^{[7]}$

Çalışma saati kısıtlamaları dolayısıyla, asistan eğitimi veren bir klinik eğitime ayırdığı zamanı iyi developed over the years to be more comprehensive, and the number of participants has been steadily rising. Since 2011, the EBOT Exam consists of two parts, which are both carefully prepared to cover the entire curriculum content consisting of elective orthopaedics, trauma, and basic science. Each of the two parts is organized once every year.

The Federation of Orthopaedic Trainees in Europe (FORTE) is playing a major role in orthopaedic residents training and education. FORTE is working on producing educational material that will complement training and preparation for the EBOT Exam. Currently, FORTE is preparing a Study Guide Book Series that will cover all aspects of orthopaedics and traumatology and aims to serve as a guide for residents and fellows who are preparing for their residency or board examinations. Furthermore, FORTE is closely collaborating with OrthoBullets (ww.orthobullets. com) to establish an e-learning system for orthopaedic residents.

\section{DISCUSSION}

The American Board of Orthopaedic Surgery (ABOS) does outline time requirements for orthopaedic residents assessing that "minimum distribution of educational experience must include: 1) twelve months of adult orthopaedics; 2) twelve months of fractures/trauma; 3 ) six months of children's orthopaedics; 4) six months of basic and/or clinical specialties". Nevertheless, the work-hour restrictions implemented within the past decade in both Europe and United States limit the actual experiential opportunity for residents. ${ }^{[17]}$ Many have expressed concern that, due to the decreased time available, residents not only take much longer to accumulate the necessary clinical experience, but may not be adequately acculturated to the values of the profession. The purpose of a residency should be to create clinicians who are proficient and who can independently perform procedures that a general orthopaedist would be expected to be able to perform. ${ }^{[17]}$

Currently, there is growing need for alternative methods to train in surgical skills outside the OR environment. ${ }^{[7]}$ Cadaver training has been part of surgical education since the 16 th century, ${ }^{[18]}$ and it has remained the benchmark of the trainee's surgical practice before beginning to operate on living patients. ${ }^{[19]}$ The main advantage of this type of skills training is that the trainee is exposed to real anatomy. ${ }^{[7]}$ In the latter half of the 20th century, synthetic or plastic bone models were developed to replace cadaver bones and to serve as reproducible models to aid in the development of 
planlamalı, ama daha önemlisi, bir asistanın nasıl öğrendiğini anlamalıdır. Cerrahi becerileri kısıtlı ve gerektiğinden az öğrenmiş riskli grup asistanları bu sayede belirleyebilir ve onlara akademik eğitimi daha iyi verebilir. ${ }^{[20]}$ Her ne kadar teknoloji asistanların öğrenme sürecinde çok önemli bir unsur olsa da, genellikle onlar bu teknolojiyi cevaplanmamış sorulara bir çırpıda çözüm bulmak için kullanabileceklerini sanarlar. Bir diğer sorun da, asistanların kendilerini ortopedinin temellerini öğrenmek zorunda olan eğitilenler olarak değil de, onlardan beklenen hedeflerin ötesinde, geleceğin uzmanları olarak görmeleridir. ${ }^{[17]}$

Ortopedi asistan eğitimini daha etkin ve üretken yapmak için, uzmanların ve eğitim sorumlularının öncelikle Avrupa ve ABD arasındaki çalışma saati kısıtlama farkları üzerinde yoğunlaşmaları gerekir. ABD'de ortopedi asistanı eğitim süresinin 2003'te 80 saatle sınırlanması sonrası, eğitim olanaklarında, özellikle cerrahi tecrübede belirgin azalma olmuştur. Bize göre bu, ortopedi camiasındaki ana tartışmalardan birisi olmalıdır ve ulusal cemiyetler ve ortopedi asistanı organizasyonları (FORTE vb.) bu konudaki girişimlerde lider rolü oynamalıdır. Son olarak; sadece çalışma saati kısıtlamalarını değil, asistanların nasıl tecrübeler edindiğini ve bu tecrübeleri eğitimleri süresince nasıl değerlendirdiklerini de incelemek gerekir. ${ }^{[17]}$ basic orthopaedic surgical skills, and they have been found to be important in the orthopaedic residents training process. During the past decade, many orthopaedic residency programs have set up their own surgical skills laboratories which are intended to allow trainees to practice basic surgical skills in a risk-free, low-stress environment. Furthermore, simulationbased surgical training methods that are available for orthopaedic trainees include hands-on training in surgical skills laboratories using synthetic or cadaver bones, PC-based training using software, and computerized simulators. Simulator-based arthroscopy training has gained particular importance owing to rapidly expanding indications for arthroscopic surgery. ${ }^{[7]}$

With work-hour restrictions, residency programs must optimize time for education and most important they have to understand how they learn. The latter can facilitate identifying those residents at risk of underperforming in surgical skill acquisition and can make academic teaching more effective. ${ }^{[20]}$ However, although technology has become an integral component in the way in which residents learn, they often believe that they can use that technology to instantaneously find solutions to unanswered questions. Moreover, there is a perception that residents during their training begin to view themselves more as future specialists than trainees who need to learn the fundamentals of orthopaedics beyond their anticipated area of discipline. ${ }^{[17]}$

In order to make orthopaedic residents training more productive, experts and programme directors should first focus on existing differences between work-hour limits in Europe and in United States. It has been shown that reduction of orthopaedic resident work-hours in the United States to a maximum of 80 hours per week in 2003 to cause a significant reduction in training opportunities, particularly operative experience. In our opinion, it should be one of the main topic of discussion in the orthopaedic community and we strongly believe that National Societies and Orthopaedic Residents Organizations (i.e. FORTE) can lead the way about this important issue. Finally, we should not only focus on residents work hourlimits, but also we should pay more attention on the type of experiences the resident is having and how the resident reflects on these experiences during their orthopaedic training. ${ }^{[17]}$ 


\section{KAYNAKLAR / REFERENCES}

1. Green SA, Poole GD. Resident work hours: Examining attitudes toward work-hour limits in general surgery, orthopaedics, and internal medicine. BC Med J 2010;52:84-8.

2. Kairys JC, McGuire K, Crawford AG, Yeo CJ. Cumulative operative experience is decreasing during general surgery residency: a worrisome trend for surgical trainees? J Am Coll Surg 2008;206(5):804-11; discussion 811-3. CrossRef

3. Damadi A, Davis AT, Saxe A, Apelgren K. ACGME duty-hour restrictions decrease resident operative volume: a 5-year comparison at an ACGME-accredited university general surgery residency. J Surg Educ 2007;64(5):256-9.

4. Schneider JR, Coyle JJ, Ryan ER, Bell RH Jr, DaRosa DA. Implementation and evaluation of a new surgical residency model. J Am Coll Surg 2007;205(3):393-404.

5. Romanchuk K. The effect of limiting residents' work hours on their surgical training: a Canadian perspective. Acad Med 2004;79(5):384-5.

6. Wolf BR, Britton CL. How orthopaedic residents perceive educational resources. lowa Orthop J 2013;33:185-90.

7. Atesok K, Mabrey JD, Jazrawi LM, Egol KA. Surgical simulation in orthopaedic skills training. J Am Acad Orthop Surg 2012;20(7):410-22. CrossRef

8. Beredjiklian PK, Bozentka DJ, Steinberg DR, Bernstein J. Evaluating the source and content of orthopaedic information on the Internet. The case of carpal tunnel syndrome. J Bone Joint Surg Am 2000;82-A(11):1540-3.

9. Mabrey JD. Electronic resources for the orthopaedic surgeon. J Bone Joint Surg Am 2000;82-A(10):1499-502.

10. Mabrey JD. Survey of patient-oriented total hip replacement information on the World Wide Web. Clin Orthop Relat Res 2000;(381):106-13.
11. Sinkov VA, Andres BM, Wheeless CR, Frassica FJ. Internetbased learning. Clin Orthop Relat Res 2004;(421):99-106.

12. Syed S, Mirza AH, Ali A. A brief comparison of orthopaedic training in English-speaking countries. Ann R Coll Surg Engl 2009;91(3):226-31. CrossRef

13. Marker DR, Mont MA, McGrath MS, Frassica FJ, LaPorte DM. Current hand surgery literature as an educational tool for the orthopaedic in-training examination. J Bone Joint Surg Am 2009;91(1):236-40. CrossRef

14. Krueger CA, Shakir I, Fuller BC. Prevalence of answers to orthopaedic in-training examination questions in 3 commonly used orthopedic review sources. Orthopedics 2012;35(9):e1420-6. CrossRef

15. Stahel PF, Flierl MA. Orthopedic residency training in Germany: an endangered species? Orthopedics 2008;31(8):742-3.

16. Mäkinen TJ, Madanat R, Kallio P, Mineiro J, Kiviranta I. The current state of the fellowship examination of the European Board of Orthopaedics and Traumatology (EBOT). Eur Orthop Traumatol 2013. [Epub] CrossRef

17. Black KP, Alman BA, Levine WN, Nestler SP, Pinney SJ. Orthopaedic resident education--it's a whole new game: „If I'm going to be a spine surgeon, why do I need to learn how to reconstruct an anterior cruciate ligament?": AOA critical issues. J Bone Joint Surg Am 2012;94(13):e96. CrossRef

18. Ferrari G. Public anatomylessons and the carnival: the anatomy theatre of Bologna. Past Present 1987;(117):50-106.

19. Holland JP, et al. Cadaveric hands-on training for surgical specialties: is this back to the future for surgical skills development? J Surg Educ 2011;68(2):110-6. CrossRef

20. Richard RD, Deegan BF, Klena JC. The learning styles of orthopedic residents, faculty, and applicants at an academic program. J Surg Educ 2014;71(1):110-8. CrossRef 